\title{
Sources of Growth and Spatial Concentration of Coconut Crop in the State of Pará, Brazilian Amazon
}

\author{
Paulo Silvano Magno Fróes Júnior ${ }^{1}$, William Lee Carrera de Aviz ${ }^{1}$, Fabrício Khoury Rebello ${ }^{1}$ \\ \& Marcos Antônio Souza dos Santos ${ }^{1}$ \\ ${ }^{1}$ Programa de Pós-Graduação em Agronomia, Universidade Federal Rural da Amazônia, Belém, Pará, Brazil \\ Correspondence: Fabrício Khoury Rebello, Programa de Pós-Graduação em Agronomia, Universidade Federal \\ Rural da Amazônia, Belém, Pará, Brazil. E-mail: fabriciorebello@hotmail.com
}

Received: September 21, 2018

Accepted: November 4, $2018 \quad$ Online Published: January 15, 2019

doi:10.5539/jas.v11n2p159

URL: https://doi.org/10.5539/jas.v11n2p159

\begin{abstract}
The State of Pará contributes to approximately $10.10 \%$ of the Brazilian production of coconut (Cocos nucifera L.). It is an important center of production for the crop, mainly due to some factors such as its edaphoclimatic conditions that are favorable for the plant development, the availability of rural credit and the presence of business groups with expertise on the activity and agro industrial processing. This survey used data from Instituto Brasileiro de Geografia e Estatística (IBGE) (2018) to make an analysis of the activity in the state between 1974 and 2016, evaluating by the Shift-Share Analysis the sources of production growth, harvested area and productivity. Furthermore, the study also analyses the evolution of coconut prices, concentration and specialization of some micro regions of the State in coconut crop production using the Locational Gini Coefficient and Location Quotient. The main results show an expressive increase in coconut production in the state of Pará economy since the 1980s, showing that between 1974 and 2016 the production increased by $9.41 \%$ per year, the harvested area $7.88 \%$ p.a. and productivity $1.42 \%$ p.a. It is also possible to observe an expressive concentration and specialization of the activity in the Micro region of Tomé-Açu, responsible for $57.40 \%$ of the state production.
\end{abstract}

Keywords: agribusiness, coconut, locational gini coefficient, location quotient, shift-share analysis

\section{Introduction}

Coconut crop is an important agricultural activity for the Brazilian economy. Rebello, Reale Filho and Figueiredo (2003) argue that this sector is responsible for a productive chain with more than 100 products consisting of in natura consumption of the seed and water, as well as industrial items for production of food, textile products, upholstery, animal food, and others.

Still, according to the authors mentioned above, due the possible use of the palm tree (from which one can use the roots, the stipe, the inflorescence, the leaves, the heart of palm and mainly the solid and liquid albumen), the activity provides jobs for rural workers and permit their permanence in agrarian regions. Moreover, it can create works inside and outside the farms in agro industrial activity and commerce.

The State of Pará is considered a Brazilian state with great potential in the coconut crop economy, due to its edaphoclimatic characteristics proper to the production tropical cultures, and the presence of supporting services to production such as the availability of rural credit and know-how of the activity at the business level. At the moment, the state is the fourth biggest national producer with a participation of $10.10 \%$ (IBGE, 2018).

In Brazil, the development of coconut crop is concentrated mainly in the Northeastern Region, being the State of Bahia the biggest national producer. However, in the Brazilian scenario, this crop is commonly adopted as an extractivist or semi-extractivist system, showing a productivity highly influenced by the expansion of farming areas, rather than due to technological resources. In the case of Pará, because the presence of large business group and the availability of rural credit for small farmers, it is observed the occurrence of a highly technified system which also radiates to some smaller initiatives.

This study brings a contextualization about the coconut scenario in the State of Pará, from an analysis of the evolution of the sources of growth: production, harvested area, productivity and prices between 1974 and 2016 . It also measures the level of regional specialization and the spatial concentration of the activity in the State. 


\subsection{Coconut Panorama at State of Pará}

About 48 years ago, during the 1970s, coconut crop had already shown itself as an important economic activity in the Brazilian Northeast. However, at the time, the production of coconut was not significantly and broadly explored into other regions of the Country, either.

According to data from Food and Agriculture Organization of the United Nations (FAO, 2018) in the 1970s, Brazil was at the $9^{\text {th }}$ largest producer of coconut in the world. Today, it is the $4^{\text {th }}$ largest producer, behind some Asian countries such as Indonesia $\left(1^{\text {st }}\right)$, Philippines $\left(2^{\text {nd }}\right)$ and India $\left(3^{\text {rd }}\right)$.

Gutierrez Cuenca and Costa (2001) state that the Northeast production, in 1942, represented 99\% of the Brazilian production, and only in the 1980s the activity expanded in other regions, except the southern region.

In that period, the State Pará had no relevance in the Brazilian coconut production. However, at the end of 1970s and early 1980s, some renowned companies from the Brazilian Northeast found out great opportunities to open new business in the Amazonian region.

One of these enterprises with a significant economic importance in the region is the Socôco group with headquarters in Maceió, State of Alagoas, which, according with Rebello, Reale Filho and Figueiredo (2003), made a large investment in coconut cultivation in the Municipality of Moju, State of Pará aiming locational advantages due to its favorable edaphoclimatic and the possibility of a vertical integration. The cultivated area in Moju is considered the largest continuous area of coconut crop in the world. Therefore, the State of Pará is considered an important area for the development of coconut cultivation.

According to Lins and Viégas (2008), only around the 1990s coconut started to open new frontiers in regions that were not, until then, traditional coconut producers. The State of Pará and other parts of the country increased the coconut production which had been mainly concentrated in the Northeast.

In 2016, according to data from IBGE (2018), the production of coconut in the Northeast was equivalent to $76.74 \%$ of the National Production. The Northern region contributes to $11.06 \%$, and only the state of Pará was around $10.10 \%$, or $91 \%$ of coconut production for this region.

The State of Pará is the $4^{\text {th }}$ largest Brazilian producer, behind Bahia $\left(1^{\text {st }}\right)$, Ceará $\left(2^{\text {nd }}\right)$ and Sergipe $\left(3^{\text {rd }}\right)$. The Municipalities of Moju (with $42.61 \%$ of production) and Acará (11.78\%) are the largest producers, concentrating $54.39 \%$ of the state production (IBGE, 2018). According to Lins and Viegas (2008) the rest of the production is distributed through other Pará municipalities, in farms no larger than 10 hectares, with low levels of technology for the crop development, not different from other productions in the country.

\section{Methods}

The research was made in the State of Pará located in the Northern Region of Brazil which also includes eight other states forming the Brazilian Amazon. It is the second-largest state of Brazil in area, with 1,247,955.238 square $\mathrm{km}^{2}$. It is divided into 144 municipalities, six mesoregions and 22 microregions. The micro-regions were defined for statistical puposes by Instituto Brasileiro de Geografia e Estatística (IBGE) and have specificities according to the State of Pará space organization. The micro-regions are Belém, Bragantina, Cametá, Castanhal, Conceição do Araguaia, Furos de Breves, Guamá, Itaituba, Marabá, Óbidos, Paragominas, Parauapebas, Portel, Redenção, Salgado, Santarém, São Félix do Xingu, Tomé-Açu, Tucuruí.

To develop this study, a time series data from 1974 to 2016 were used for coconut crop in 22 micro regions from the State of Pará on: production, harvested area, productivity, gross value of coconut production (from permanent and temporary crops) and price of coconut fruit in the State of Pará. All data were obtained through the Sistema IBGE de Recuperação Automática (SIDRA) from (IBGE, 2018).

The Data were processed by the software Microsoft Office Excel 2016 to estimate the Location Quotient (LQ), to evaluate the regional specialization; Locational Gini Coefficient (LG), to measure the spatial concentration; and Shift-Share Analysis, to make the decomposition and quantification of sources of growth and price analysis.

In the sub items that follow, the used methods of analysis are presented, including how these instruments were used for the coconut crop temporal series in the micro regions of the Pará State.

\subsection{Methods of Regional Analysis}

In order to identify, locate and obtain data of the coconut specialization in the micro regions of Pará, methods of regional analysis were used to permit observation at the level of specialization and level of concentration of the activity in the region under study. 
According T. Mattei and T. Mattei (2018), there are several methods of regional analysis, although inside this set, it is found methods capable of characterizing the location and the specialization of a productive activity in a regional dimension.

These methods are useful to identify a behavior pattern of productive sectors in the economic space, as well as differential standards of productive structures between the various regions (T. Mattei \& T. Mattei, 2018).

The methods of regional analysis used in this study were Locational Gini Coefficient (LG) and the Location Quotient (LQ). Shown below are the basics characteristics on both indexes and their interpretations.

\subsubsection{Locational Gini Coefficient}

The Locational Gini Index (LG) is an indicator of concentration based on the coefficient developed by the Italian statistician Corrado Gini (1884-1965) in his 1912 paper "Variabilità \& Mutabilită". According to Suzigan, Furtado, Garcia, and Sampaio (2003), the model permits to indicate the level of spatial concentration of a certain economic variable in some specific geographic base (municipality, micro region, state, macro region and country).

According to Ceriani and Verme (2012) Gini defines his index as the "the mean difference from all observed quantities" and explain the difference between "Variabilită" (dedicated to measure the quantitative phenomena) and "Mutabilită" (dedicated to measure the qualitative phenomena).

The index varies from zero to one (0-1) and the more spatially concentrated is the activity, the closer it is to the unity (1), it means that the activity is spatially concentrated. If the activity is uniformly distributed in the region under study, the index will be equal to zero (0).

Although the LG is an important indicative tool of concentration, it has some limitations to identify the regions where the activity is specialized. Therefore, the Location Quotient enters as a mechanism of localization and identification of more specialized micro regions in the activity.

\subsubsection{Location Quotient}

According to T. Mattei and T. Mattei (2018) the Location Quotient (LQ) measures the relative specialization of a region in a particular activity relative to a comparison nation. It is an index used to determinate the degree of specialization of a region or municipality in some activity (Vidigal, Campos, \& Rocha, 2009; T. Mattei \& T. Mattei, 2018).

It is important to emphasize that LQ is an index of specialization, and it is not an index that characterizes the amount of production, harvested area and productivity, in other words, when a region is identified as specialized, it means, in agricultural terms, that among all the agricultural activities of a determined region, the activity submitted to the index methodology tends to be relevant among the other activities. Therefore, a region can have a very low Total Gross Production Value, while the Gross Value of Coconut Production is high in the region, showing that it is specialized, but not as a large producer.

The following mathematic equation was used to obtain Location Quotient (LQ):

$$
\mathrm{LQ}_{\mathrm{ij}}=\frac{\mathrm{GV}_{\mathrm{ij}} / \mathrm{GV}_{\mathrm{j}}}{\mathrm{GV}_{\mathrm{PA}}^{\mathrm{i}} / \mathrm{GV}_{\mathrm{PA}}}
$$

where, $G V_{\mathrm{ij}}$ : means the Gross Value of coconut production (i) at Micro region (j); $\mathrm{GV}_{\mathrm{j}}$ : Gross Value of Agricultural Production for the entire Micro Region (j); $G_{\mathrm{PA}}^{\mathrm{i}}$ : Gross value of coconut production (i) in the State of Pará (PA); $\mathrm{GV}_{\mathrm{PA}}$ : Gross Value of Agricultural Production in the State of Pará.

The interpretation of the obtained LQ value can be read as follows, according to Vidigal et al. (2009):

$\mathrm{LQ}=1$ means that the micro region specialization (j) in coconut crop (i) is the same as the specialization of the entire State of Pará (PA);

LQ $<1$ means that the micro region specialization (j) in coconut crop (i) is lower than the specialization of the State of Pará (PA) for the activity;

LQ $>1$ means that the micro region specialization (j) in coconut crop (i) is higher than the specialization of the State of Pará (PA) for the activity.

\subsection{Shift-Share Analysis}

For decomposition of sources of growth the Shift-Share Analysis was applied, which took as a base, analyses done from the quantity produced. This is an appropriate methodology that permits to identify the influence of variables of harvested area and productivity in the behavior of coconut production. 
Therefore, the variations in the amount produced were decomposed in two effects, or two sources of growth, which are: variations in the harvested area (effect-area) and variations in the yield (effect-yield).

The effect of area indicates changes in production, due to variations in cultivated area, supposing that yield, geographic location and the cultivation structure remain constant. The yield effect measures change in production due to modification in land productivity; other sources of growth remained unaltered. This change in yield can reflect technological changes, with the introduction of new inputs and production techniques.

The math model and the analytical proceedings used in this study were executed based on Homma (1981), Filgueiras (2003) and Santos, Filgueiras and Araújo (2005) who used the Shift-Share Analysis in many studies of Agricultural growth activities in the Brazilian Amazon.

\subsection{Prices Analysis}

For prices analysis study, indexes from IGP-DI of Fundação Getúlio Vargas (FGV) were used. They were obtained from the database the Instituto de Pesquisa Econômica Aplicada (IPEA, 2018) to deflate the annual prices from 1974 to 2016. Prices are expressed in December 2016 values. This procedure permitted to evaluate the prices tendency and cycles occurred during that period.

\section{Results}

\subsection{Coconut Production in the State of Pará}

When coconut crop evolution in State of Pará is analyzed for the period between 1974 and 2016, it is possible to verify that, in 2016, the coconut production was 178,345 tons, representing 19,128 hectares of harvested area and 9,324 kg per hectare (Figure 1).

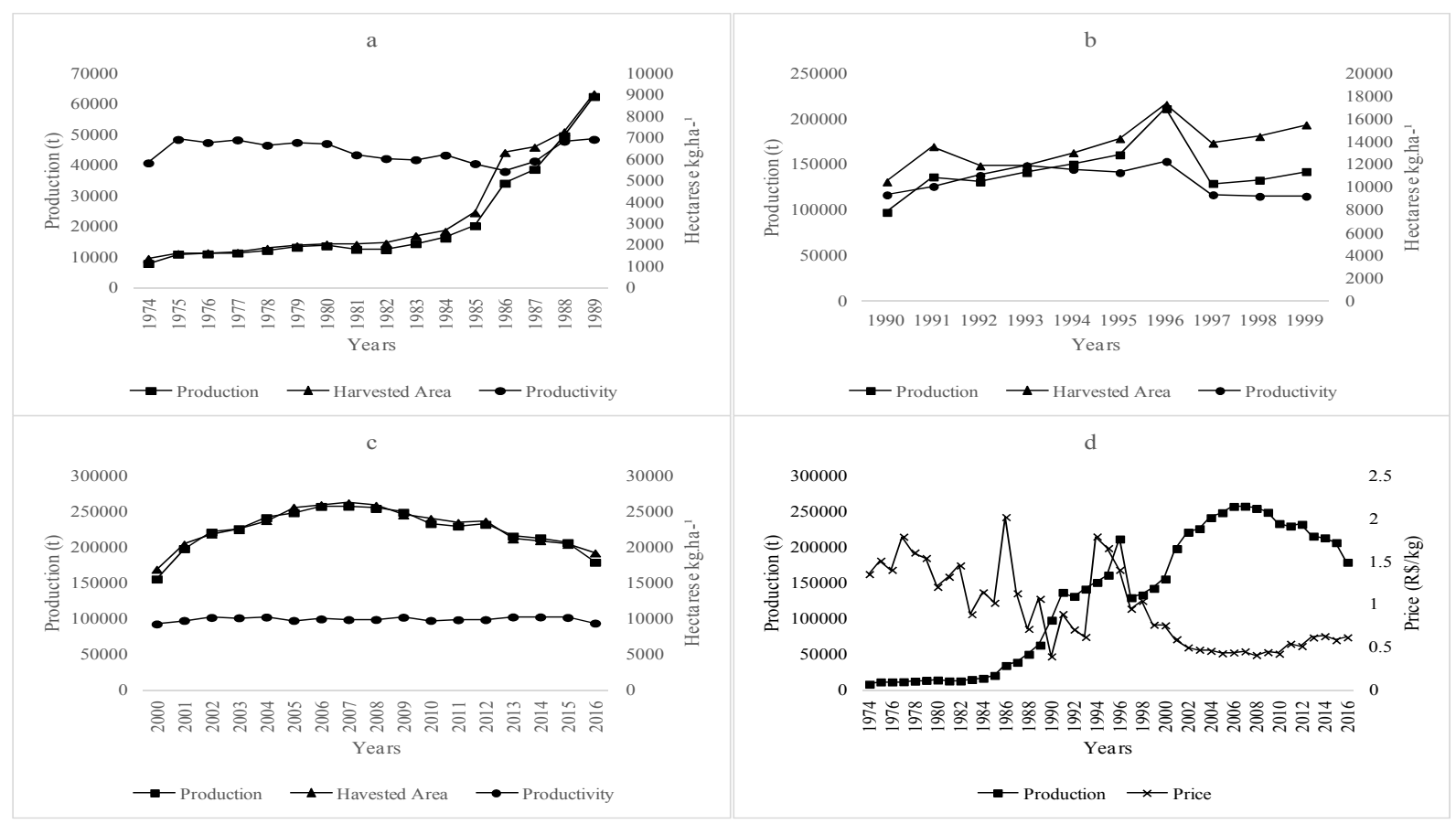

Figure 1. Evolution of production, harvested area and yield of coconut crop in the State of Pará from 1974 to 1989 (a), 1990 to 1999 (b), 2000 to 2016 (c), and Production/Price from 1974 to 2016 (d)

Source: IBGE, 2018.

For a better analysis, the evolution of production, harvested area and yield was divided into three periods, considering their distinct dynamics in the respective periods.

Observing Figure 1a, it is possible to notice that during the period between 1974 and 1989, production and harvested area had shown a growing tendency with a growth rate of $6.6 \%$ and $5.69 \%$, respectively. As for productivity, it shows stagnation during the same period, with a growth rate of $0.19 \%$. This production increase is related to the introduction of the area planted by Socôco located in the Municipality of Moju (micro region of 
Tomé-Açu) in 1979. This commercial plantation begins its productive cycle after 5 years, adopting techniques that provide high indexes of productivity.

The period between 1990 and 1999 (Figure 1b) shows variation for production, harvested area and productivity, tending to stagnation with growth rate of $0.46 \%, 0.48 \%$ and $-0.01 \%$, respectively. In 1996 production was excellent because it grew from 160,344 tons in 1995 to 210,849 tons, in 1996, with a correspondent increase in the harvested area.

In the third period studied (Figure 1c), it is evident that there is a stagnation for the three variables; production $(0.15 \%)$, harvested area $(0.14 \%)$ and productivity $(0.01 \%)$. Nevertheless, it is in 2007 that production and harvested area achieve an apex, with 256,622 tons of coconut produced in a harvested area of 26,142 hectares.

Analyzing the price evolution of coconut per kg for the period between 1974 and 2016 (Figure 1d), it is verified an inverse relation with production. During this period, prices show a decreasing tendency as production grows suffering high variations in price until the late 1900s. During that period of price fluctuations, two peaks in prices occur, in 1986 and 1995 reaching $R \$ 2.01$ and $R \$ 1.79$ respectively.

The production evolution analysis between 1990 and 2016 (Figure 2) is fundamental to identify the most important major micro regions producers of coconut at State of Pará.

When the five most important micro region producers of coconut in the years of 1990, 1995, 2000, 2005, 2010, and 2016 are emphasized, it shows that the Micro region of Tomé-Açu has been the largest producer for all the years under study, presenting a huge discrepancy from the others.

In 2016, the micro region of Tomé-Açu achieved a production of 102,370 tons, corresponding to $57.4 \%$ of the state production and evidencing the importance of the micro region for coconut production of the State of Pará. This superior achievement, as commented before, is due to the presence of Socôco plantation located in Moju.

1990

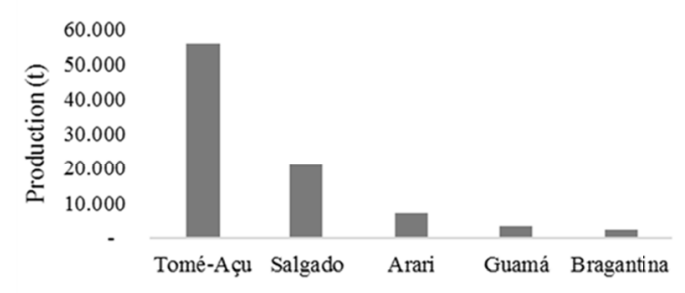

2000

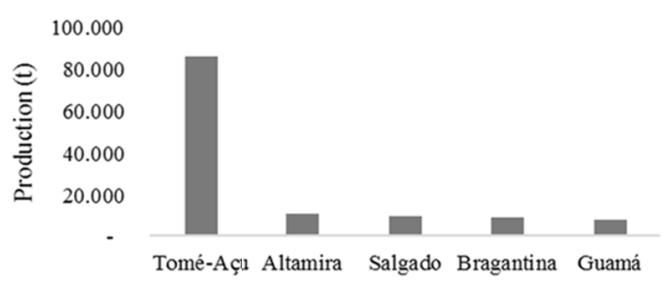

2010

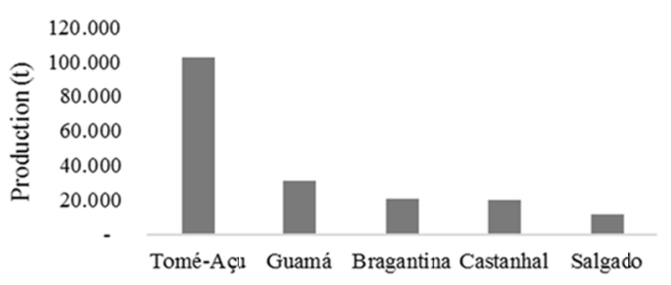

1995

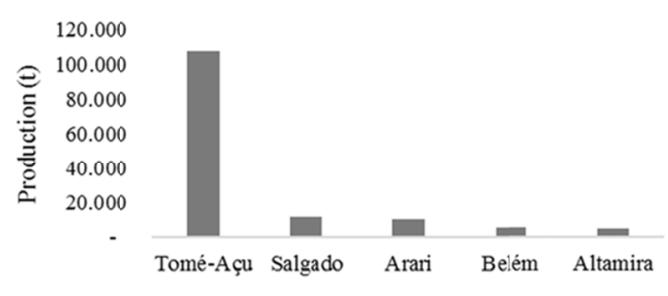

2005

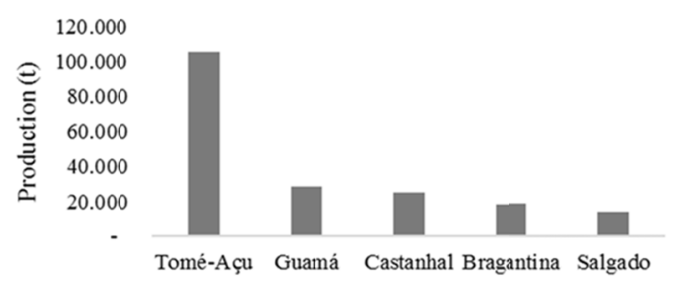

2016

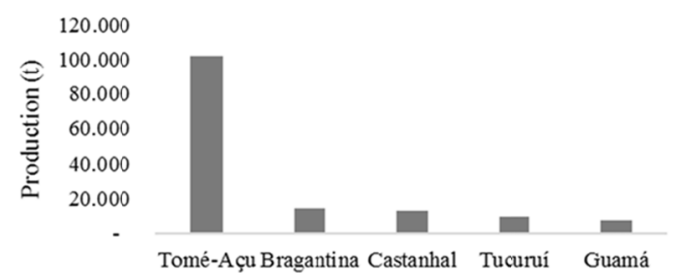

Figure 2. The five most productive micro regions of Coconut in 1990, 1995, 2000, 2005, 2010 and 2016 in the State of Pará

Between 1990 and 2016, some micro regions alternated positions among the five largest producers of coconut in the state, except Tomé-Açu that during this period had always been the number one producer. The Micro region of Salgado achieved the second position between the years of 1990 and 1995; however, its position fell along the 
years, until it was no longer among the top five micro region producers in 2016. This reduction is related to change of the main income activity of Curuçá, which was the Municipality with the greatest contribution to coconut production at micro region of Salgado.

Differently from the micro region of Salgado, the micro region of Bragantina in 2000 and 2016 increased its participation, and in 2016 it became the second major producer of coconut with 13,958 tons, corresponding to $7.8 \%$ from state production.

These alternations in production may be associated to reduction in price that occurred in the last years and by the self sufficiency of coconut processing companies that have been continuously increasing their harvested area, including productivity.

\subsection{Analyses of Locational Gini Coefficient and Location Quotient}

The Locational Gini Coefficient was used as an indicator of concentration for coconut crop at the micro regions of State of Pará. The concentration analysis was made specifically for six years (1990, 1995, 2000, 2005, 2010 and 2016) as shown on Figure 3.

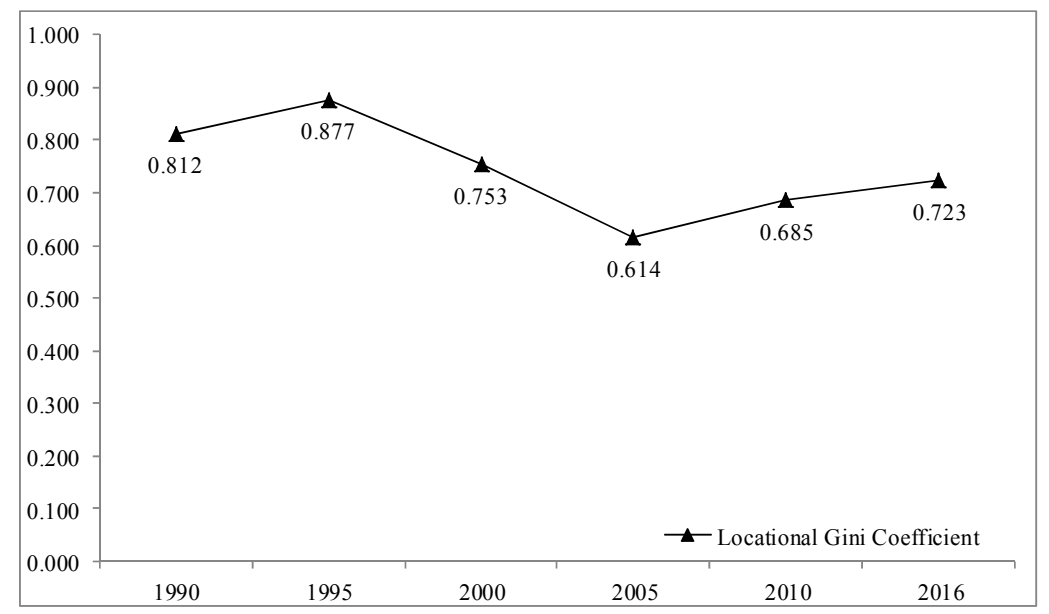

Figure 3. Evolution of Locational Gini Coefficient for the coconut at State of Pará from 1990 to 2016

Note. Meaning of the Locational Gini Values (scale from 0 to 1) - the index identifies the level of the activity concentration; On the scale, if the number is closest to " 1 ", it means that the activity is highly concentrated in the region; and when it is next to " 0 ", it means to say that there is a low concentration of the activity.

Coconut crop in the State of Pará is characterized as a very concentrated activity. It shows that 1990 and 1995 the activity presents Locational Gini Coefficients of 0.812 and 0.877 , respectively, indicating an intense activity concentration. Afterward, starting in the 2000 decade, the activity begins to deconcentrate, showing values of Locational Gini of 0.753 in 2000, and 0.614 in 2005. Despite reduction in the degree of concentration, it does not mean that the activity lost importance in the scenario, but that it opened new poles of production distributed among the other micro regions in the state. After 2005, the activity showed again an increase in the concentration index. 
Table 1. Location Quotient (LQ) into Micro regions since 1990 until 2016

\begin{tabular}{lllllll}
\hline Micro region & \multicolumn{5}{c}{ Location Quotient } \\
\cline { 2 - 7 } & 1990 & 1995 & 2000 & 2005 & 2010 & 2016 \\
\hline Óbidos & 0.10 & 0.04 & 0.09 & 0.29 & 0.06 & 0.03 \\
Santarém & 0.25 & 0.12 & 0.22 & 0.09 & 0,11 & 0.15 \\
Almeirim & 0.72 & 0.35 & 0.89 & 1.38 & 2.21 & 3.28 \\
Portel & 0.00 & 0.00 & 0.00 & 0.00 & 0.00 & 0.00 \\
Furos de Breves & 0.00 & 0.00 & 0.14 & 0.00 & 0.00 & 0.00 \\
Arari & 12.94 & 6.19 & 5.48 & 6.74 & 3.93 & 0.86 \\
Belém & 3.09 & 1.47 & 4.72 & 5.25 & 6.17 & 23.04 \\
Castanhal & 1.05 & 0.35 & 1.61 & 2.93 & 2.96 & 2.77 \\
Salgado & 11.10 & 3.49 & 3.71 & 3.53 & 3.29 & 2.74 \\
Bragantina & 0.35 & 0.51 & 1.28 & 1.36 & 1.33 & 1.40 \\
Cametá & 0.39 & 0.88 & 0.99 & 1.00 & 1.70 & 1.64 \\
Tomé-Açu & 6.06 & 6.99 & 5.29 & 2.63 & 3.40 & 4.58 \\
Guamá & 0.35 & 0.20 & 0.39 & 0.80 & 1.00 & 0.35 \\
Itaituba & 0.26 & 0.24 & 1.04 & 0.70 & 0.52 & 0.25 \\
Altamira & 0.50 & 0.36 & 1.16 & 1.08 & 0.61 & 0.14 \\
Tucuruí & 0.00 & 0.15 & 0.18 & 2.09 & 1.77 & 1.61 \\
Paragominas & 0.03 & 0.02 & 0.13 & 0.25 & 0.21 & 0.07 \\
São Félix do Xingu & 0.00 & 0.00 & 0.14 & 0.54 & 0.10 & 0.14 \\
Parauapebas & 0.00 & 0.06 & 0.24 & 0.85 & 0.72 & 1.10 \\
Marabá & 0.04 & 0.23 & 0.37 & 1.02 & 1.33 & 1.86 \\
Redenção & 0.00 & 0.00 & 0.21 & 1.04 & 0.40 & 0.74 \\
Conceição do Araguaia & 0.00 & 0.00 & 0.01 & 0.01 & 0.04 & 0.06 \\
\hline
\end{tabular}

Note. The values in gray mean Micro regions specialized in coconut crop.

Table 1 shows that in the 1990s the specialization of coconut crop occurred only in five micro regions (Arari, Belém, Castanhal, Salgado and Tomé-Açu) of the 22 State of Pará micro regions. There is a strong relation with the values from Figure 3, where the Locational Gini is 0.812 in 1990 and 0.877 in 1995, showing the existence of concentration and specialization occurring mainly in those highlighted areas.

Starting in 2000, the Micro regions of Bragantina, Itabuna and Altamira (and in 2005-Almerim, Tucurí, Marabá and Redenção) also became specialized regions, which explains the deconcentration of the activity shown in the Figure 3 during that period $(\mathrm{LG}$ (in 2000) $=0.753 ; \mathrm{LG}($ in 2005) $=0.614)$.

In 2016, there were 10 specialized micro regions, notably in Belém and Tomé-Açu, where the agro industrial unity of Sococô group and its largest plantation are located, respectively. The micro regions of Castanhal, Salgado, Cametá and Bragantina are areas that surround Belém, the capital of Pará. They have been specializing in offer the fruit with the objective of meet a strong demand for coconut water in natura, which has grown at various places in the city of Belém.

\subsection{Sources of Growth in Coconut at State of Pará}

To further detail the evolution of coconut crop at State of Pará, Table 2 presents the annual geometric growth rate of coconut production in the State of Pará micro regions between 1990 and 2016. 
Table 2. Decomposition for Sources of Growth for Coconut production in the State of Pará, per Micro regions, 1990-2016

\begin{tabular}{|c|c|c|c|}
\hline \multirow{2}{*}{ Micro regions } & \multicolumn{3}{|c|}{ Sources of growth (\% p.a.) } \\
\hline & Production & Harvested Area & Yield \\
\hline Óbidos & 1.28 n.s. & 1.12 n.s. & 0.16 n.s. \\
\hline Santarém & $2.39 * *$ & $1.53 * *$ & $0.85 * *$ \\
\hline Almeirim & $6.74 * *$ & $5.87 * *$ & $0.82 * *$ \\
\hline Portel & - & - & - \\
\hline Furos de Breves & - & - & - \\
\hline Arari & $-6.29 * *$ & $-5.26 * *$ & $-1.08 * *$ \\
\hline Belém & $2.92 *$ & 0.46 n.s. & $2.45 * *$ \\
\hline Castanhal & $12.33 * *$ & $9.8 * *$ & $2.31 * *$ \\
\hline Salgado & $-1.79 * *$ & $-3.02 * *$ & $1.27 * *$ \\
\hline Bragantina & $9.29 * *$ & $6.91 * *$ & $2.23 * *$ \\
\hline Cametá & $5.9 * *$ & $6.09 * *$ & -0.18 n.s. \\
\hline Tomé-Açu & 0.74 n.s. & $2.25 * *$ & $-1.48 * *$ \\
\hline Guamá & $10.36 * *$ & $5.28 * *$ & $4.29 * *$ \\
\hline Itaituba & 1.83 n.s. & $3.04 *$ & $-1.51 * *$ \\
\hline Altamira & $4.48 *$ & $4.69 *$ & -0.2 n.s. \\
\hline Tucuruí & $17.36 * *$ & $17.74 * *$ & -0.32 n.s. \\
\hline Paragominas & $13.09 * *$ & $10.45 * *$ & $2.39 * *$ \\
\hline São Feliz do Xingu & -0.37 n.s. & 3.21 n.s. & $-3.47 *$ \\
\hline Parauapebas & $8.96 * *$ & $10.98 * *$ & $-1.82 * *$ \\
\hline Marabá & $19.1 * *$ & $17.12 * *$ & $1.69 * *$ \\
\hline Redenção & 4.3 n.s. & $7.16 * *$ & -2.68 n.s. \\
\hline Conceição do Araguaia & $14.81 * *$ & $12.38 * *$ & 2.16 n.s. \\
\hline
\end{tabular}

Note. **: Significant in 1\% of probability; *: Significant in 5\% of probability; n.s.: Not significant.

Source: Research data (2018).

Among the micro regions, it is important to mention that Marabá achieved the highest annual increase with 19.1\%, Tucuruí (17.3\%), Conceição do Araguaia (14.8\%), Paragominas (13.1\%) and Castanhal (12.3\%). The micro regions of Portel and Furo de Breves did not show production in any of their municipalities.

All 5 micro regions listed above achieved an increase in production, however, this increase resulted from an increase in the harvested area, not in productivity.

The micro regions of Arari and Salgado showed a decrease in the growth rate with $-6.2 \%$ and $-1.7 \%$, respectively. Production decrease reduction in Arari occurred in both the planted area and productivity, being the later even greater. The micro region of Salgado had a decrease in its productivity due to a reduction in the planted area $(-3.0 \%)$, losing space, throughout the years mainly by reduction of harvested area in the Municipality of Curuçá (IBGE, 2018).

The micro region of Belém is important because it is the only one that had an increase of $2.9 \%$ in coconut production caused by an annual growth in productivity of $2.4 \%$. Also important is the micro region of Guamá with a production increase of $10.36 \%$, being productivity responsible for $4.29 \%$, the largest growth of all micro regions. This gain in productivity occurs because the Municipality of Capitão-Poço increased its production area from $6,000 \mathrm{Kg}$ per hectare, in 1979 , to $15,600 \mathrm{Kg}$ per hectare in 2015 , with a productivity closer to that obtained by the Municipality of Moju, the largest producer of coconut in the State of Pará.

In general, increase of coconut production in State of Pará is related to an increase in the planted area, although there are places with high levels of applied technology in the system of production that provides a high productivity. Foley et al. (2011) state that these increases in coconut production caused by an expansion in planted area and not in productivity are harmful to the environment resulting in a crop that does not provide a sustainable production. It shows that it is necessary to disseminate technologies already developed and used in commercial planting. 


\section{Discussion}

For the last 43 years, the coconut economy in the State of Pará has shown a positive evolution with gains in production, harvested area and productivity. This scenario has a significant and direct relation with the installation of large economic groups specialized in this sector, such as Socôco group that implemented the largest plantation of coconut crop in the world, in the Municipality of Moju in the State of Pará. The arrival of new entrepreneurs in the activity was very important. Other relevant aspect was the supply of credit with the creation of Fundo Constitucional de Financiamento do Norte (FNO), operated by Banco da Amazônia (BASA), as a way to propitiate the introduction of small producers in the activity.

The state of Pará scenario, during this time, suffered an important improvement caused by these business initiatives, including that provided by the agro industry. It became a national reference for this crop, enabling the opening of many jobs both inside and outside the farms.

As for price, high variations are observed until the year 2000. After that, the analyzed variable tends to behave in a stable way, but below prices prior to 2000 , evidencing the principles of the supply and demand law considering that in the 1980s when production was low in the State, the prices were higher reaching $\mathrm{R} \$ 2.01$ per $\mathrm{Kg}$ in 1986 , and $\mathrm{R} \$ 1.79$ per $\mathrm{Kg}$ in 1995 . This product/price relation changes during the transition toward the $21^{\text {st }}$ Century, because expansion in product supply leads to a fall in prices to the producer by $\mathrm{R} \$ 0.50 / \mathrm{kg}$. stimulating the commercializing of products in natura at the local Pará market.

As for the concentration of coconut production, it was perceived that the crop, between 1990 and 1995 , presented a Locational Gini Coefficient of 0.812 and 0.877, meaning that coconut crop during that period was concentrated. In 2005, the index had shown a lower concentration of production with 0.614 , and in the following years it showed an increase of concentration, reaching the Locational Gini Coefficient of 0.723 in 2016.

By association, with specialization data, it is observed that the micro regions of Belém, Tomé-Açu and Salgado are specialized in the crop during all years under analysis. However, the highest volume of production is located at the Micro region of Tomé-Açu, in the Municipality of Moju (Socôco Farm) and in Acará. The survey reveals that there was a growth in production of coconut in most of the Micro regions, mainly in Marabá, Tucuruí, Conceição do Araguaia, Paragominas and Castanhal. This shows an expressive production growth caused by an increase in harvested area at these localities. The micro regions of Guamá and Belém show a good performance in productivity.

It is important to emphasize that expansion of coconut at State of Pará had a tendency of growth in planted area replacing other productive activities with low financial return or phytosanitary problems.

Even under this favorable context, there are still several challenges to be overcome by coconut crop of the state of Pará. Among them, it should be mentioned the subject of extensive and semi extensive systems of production in many rural properties; the consolidation of agrarian practices that are favorable for gains of production through productivity by the yield; and incentive for Capital Stock that is really low in the region. All these factors are important challenges to be surpassed, but that may transform the Amazonian Scenario into an economic potential in coconut crop, and an example of sustainable development.

\section{References}

Ceriani, L., \& Verme, P. (2012). The origins of the Gini index: Extracts from "Variabilità e Mutabilità" (1912). by Corrado Gini. Journal of Economic Inequality, 10, 421- 443. https://doi.org/10.1007/s10888-011-9188-x

Lins, P. M. P., \& Viégas, I. J. M. (2008). Adubação do Coqueiro no Pará (Embrapa Amazônia Oriental. Documentos, 350, p. 29). Embrapa Amazônia Oriental. Retrieved from https://www.infoteca.cnptia. embrapa.br/bitstream/doc/410085/1/Doc350.pdf

Filgueiras, G. C. (2003). Fontes de crescimento do setor agrícola no Estado do Pará: Avaliação pelo método Shift-Share. In H. Graça (Eds.), O meio Amazônico em Desenvolvimento: Exemplos de alternativas econômicas (p. 231-262). Banco da Amazônia S/A.

Foley, J. A., Ramankutty, N., Brauman, K. A., Cassidy, E. S., Gerber, J. S., Johnston, M., ... Zaks, D. P. M. (2011). Solutions for a cultivated plantet. Nature, 478, 337-342. https://doi.org/10.1038/nature10452

FAO (Food and Agriculture Organization of the United Nations). (2018). Production of Coconuts: Top 10 producers. Retrieved from http://www.fao.org

Gutierrez Cuenca, M. A., \& Costa. W. V. (2001). Estatísticas da cocoicultura no Brasil: 1942 a 2001 (Embrapa Tabuleiros Costeiros. Documentos, 291, p. 67). Embrapa Tabuleiros Costeiro. Retrieved from 
https://ainfo.cnptia.embrapa.br/digital/bitstream/item/64522/1/cpatc-documentos-29-estatisticas-da-cocoicul tura-no-brasil-1942-2001-lv-2008-00764.pdf

Hoffmann, R., Engler, J. J. C., Serrano, O., Thame, A. C. M., \& Neves, E. M. (1978). Administração da empresa agrícola (3rd ed.). São Paulo, Pioneira.

Homma, A. K. O. (1981). Fontes de crescimento da agricultura paraense, 1970/80 (Boletim de Pesquisa, 27). EMBRAPA, CPATU. Retrieved from http://ainfo.cnptia.embrapa.br/digital/bitstream/item/31891/1/CPATU -BP27.pdf

IBGE (Instituto Brasileiro de Geografia e Estatística). (2018). Produção Agrícola Municipal. Retrieved from http://www.ibge.gov.br

Igreja, A. C. M., Carmo, M. S., Galvão, C. A., \& Pellegrini, R. M. P. (1983). Análise quantitativa do desempenho da agricultura paulista, 1966-77. Agricultura em São Paulo, 30, 11-158.

IPEA (Instituto de Pesquisa Econômica Aplicada). (2018). Retrieved from http://www.ipeadata.gov.br

Mattei, T., \& Mattei, T. (2018). Métodos de Análise Regional: Um estudo de localização e especialização para a Região Sul do Brasil. Revista Paranaense De Desenvolvimento, 38(133), 227-243.

Rebello, F. K., Reale Filho, H. B., \& Figueiredo, R. N. (2003). Diagnóstico e perspectiva econômica da cadeia produtiva do coco-da-baía no Estado do Pará. In H. Graça (Eds.), O meio Amazônico em Desenvolvimento: Exemplos de alternativas econômicas (pp. 133-198). Banco da Amazônia S/A.

Santos, M. A. S, Filgueiras, G. C, \& Araújo, M. S. P. (2005). Avaliação das fontes de crescimento da Dendeicultura no estado do Pará no período 1990-2003. Proceeding of XLIII Congresso Brasileiro de Economia e Sociologia Brasileiro de Economia e Sociologia Rural. SOBER.

Suzigan, W., Furtado, J., Garcia, R., \& Sampaio, S. E. K. (2003). Coeficientes de Gini locacionais-GL: Aplicação à indústria de calçados do Estado de São Paulo. Nova Economia, 13, 36-60.

Vidigal, V., Campos, A., \& Rocha, C. (2010). Especialização Produtiva nos Arranjos Produtivos Locais (APL) de Calçados do Brasil, 1995-2006. Estudos do CEPE, O(30), 30-53.

\section{Copyrights}

Copyright for this article is retained by the author(s), with first publication rights granted to the journal.

This is an open-access article distributed under the terms and conditions of the Creative Commons Attribution license (http://creativecommons.org/licenses/by/4.0/). 